
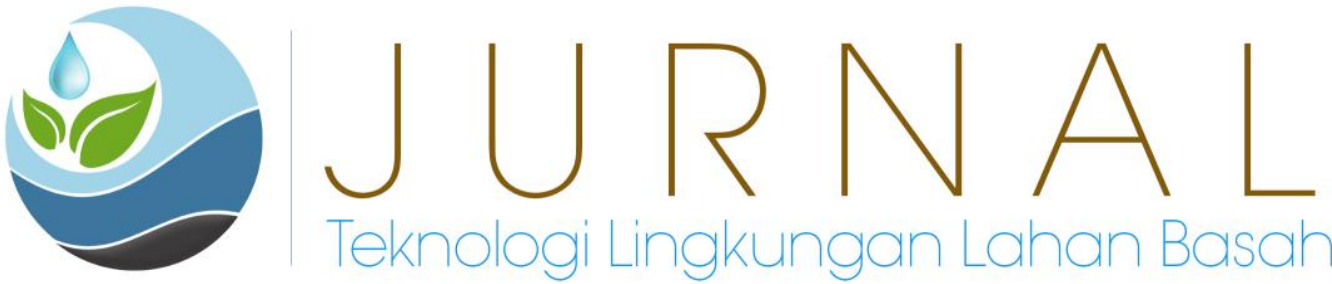

\title{
KAJIAN REZIM HIDROLOGI DAN SALINITAS DAS LANDAK- KAPUAS DALAM RANGKA PENGEMBANGAN SUMBER AIR BAKU SPAM REGIONAL PONTIANAK - ZONA HUJAN EQUATORIAL
}

\author{
Ricka Aprillia ${ }^{1}$ dan Arwin Sabar ${ }^{2}$ \\ ${ }^{1}$ Teknik Lingkungan Universitas Nahdlatul Ulama Kalimantan Barat \\ ${ }^{2}$ Teknik Lingkungan Institut Teknologi Bandung \\ Email: ${ }^{1}$ rickaaprillia1990@gmail.com dan ${ }^{2}$ arwinsabar@yahoo.com
}

\begin{abstract}
The existence of sustainable development plan in kapuas coastal areas toward Pontianak Metropolitan Cities, requires a decent source of raw water in terms of quality, quantity and continuity according to national standards. This study discusses the hydrological regime for the reliability of raw water source (quality and quantity) of interbasin Ambawang River Landak River (Biyung) were selected as new raw water source for drinking water infrastructure development Regional Pontianak. The results showed that Ambawang River periodically affected by tidal and seawater interution, so the dam was built to break salinity. While the Landak River (Biyung) has a random discharge and is influenced by rainfall. The result of the division of discharge Discrit Markov against salinity values showed that, the highest salinity occurs in dry climates, dry month and daily discharge dry where the amplitude tidal estuary maximum. The minimum daily discharge Landak River recorded in 1997 at $21 \mathrm{~m}^{3} / \mathrm{sec}$ analog with $\mathrm{R}_{20}$ daily discharge plan of $23.38 \mathrm{~m}^{3} / \mathrm{sec}$. Pontianak Regional raw water needs of $4.6 \mathrm{~m} 3 / \mathrm{sec}$ in the 2030, while the used discharge for the allocation of drinking water a debit 20 years of dry, dry $R_{20}$ on the River Ambawang of $12.05 \mathrm{~m}^{3} / \mathrm{sec}$, so the 2030 needs raw water Regional Pontianak can be met.
\end{abstract}

Keywords: raw water, drinking water, Regional Pontianak, salinity, Ambawang River, Landak River

\begin{abstract}
Abstrak
Adanya rencana pembangunan berkelanjutan di kawasan pesisir kapuas menuju Kota Metropolitan Pontianak, memerlukan sumber air baku yang layak dari segi kualitas, kuantitas dan kontinuitas sesuai standar nasional. Penelitian ini membahas mengenai rezim hidrologi untuk keandalan sumber air baku (kualitas dan kuantitas) dari Sungai Ambawang interbasin Sungai Landak (Biyung) yang terpilih dijadikan sumber air baku yang barudalam pengembangan infrastruktur air minum Regional Pontianak. Hasil penelitian menunjukkan bahwa Sungai Ambawang secara periodik terpengaruh pasang surut yang berpotensi terinterusi air laut, sehingga dibangun bendungan untuk memutus salinitas. Sedangkan Sungai Landak (Biyung) memiliki debit yang acak dan dipengaruhi oleh curah hujan. Hasil pembagian debit Discrit Markov terhadap nilai salinitas menunjukkan bahwa, salinitas tertinggi terjadi pada iklim kering, bulan kering dan debit harian kering dimana amplitudo pasut di muara sungai maksimum. Debit harian minimum Sungai Landak tercatat pada tahun
\end{abstract}



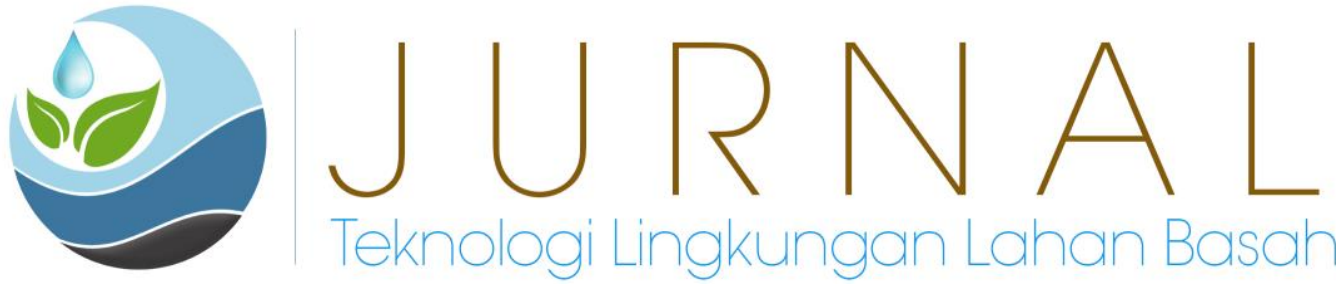

1997 sebesar $21 \mathrm{~m}^{3} /$ detik analog dengan debit rencana $R_{20} 1$ harian sebesar 23,38 $\mathrm{m}^{3} /$ detik. Kebutuhan air baku Regional Pontianak sampai dengan tahun 2030 sebesar 4,6 $\mathrm{m}^{3} /$ det sedangkan debit untuk alokasi air minum menggunakan debit 20 tahun kering, $R_{20}$ kering pada Sungai Ambawang sebesar 12,05 $\mathrm{m}^{3} /$ det, sehingga sampai dengan tahun 2030 kebutuhan air baku Regional Pontianak dapat terpenuhi.

Kata kunci: air baku, air minum, Regional Pontianak, salinitas, Sungai Ambawang, Sungai Landak.

\section{PENDAHULUAN}

Adanya rencana pembangunan berkelanjutan di kawasan pesisir Kapuas (berkarakter zona equatorial dan pasang surut semi diurnal) menuju Kota Metropolitan Pontianak yang terdiri dari Kota Pontianak, Kabupaten Kubu raya, dan Kabupaten Pontianak.

Dari segi kuantitas, ketersediaan air baku cukup berlimpah, namun dari segi kualitas, sumber air baku Kota Pontianak terancam interusi air laut pada tahun normal dan tahun kering di musim kemarau. Intrusi air laut cenderung meningkat di masa depan karena debit sungai berkurang, peningkatan pengambilan air di hulu serta perubahan iklim jangka panjang (Khan dkk, 2011).

Sehingga rambatan pasang surut semakin meningkat menuju daratan. Saat intake di Kota Pontianak terinterusi air laut, pengambilan air baku dialihkan ke Intake cadangan Penepat dan hanya melayani $30 \%$ penduduk Kota Pontianak (Fitri, 2012). Namun intake cadangan Penepat

\section{METODE PENELITIAN}

Lokasi penelitian terletak di wilayah Regional Pontianak, dimulai dari muara sungai Kapuas di daerah hilir dan Sungai Landak serta Sungai Ambawang di daerah hulu. Secara geografis, dilintasi oleh garis sudah tidak bisa diandalkan saat ini karena sudah terinterusi air laut dan juga memerlukan biaya yang besar untuk pemompaan dan pengolahan.

Kualitas sumber daya air merupakan perhatian yang harus berkelanjutan sehingga penting untuk dilakukan pengelolaan untuk air baku sungai (Basu and Lokesh, 2013). Pada penelitian ini akan dikaji sumber air baku dari Sungai Ambawang interbasin Sungai Landak dan pengembangan SPAM sebagai strategi yang adaptif terhadap pengaruh pasang surut dan salinitas sehingga dapat memenuhi kebutuhan air minum di Regional Pontianak sepanjang tahun serta dalam rangka meningkatkan pelayanan infrastruktur air minum yang berkelanjutan. Sistem penyediaan air minum membutuhkan infrastruktur yang digunakan untuk produksi, transmisi, pengolahan, dan distribusi untuk dikonsumsi dengan nilai ekonomi yang baik (Ramos dkk, 2010).

Khatulistiwa yaitu pada $00^{\circ} 15^{\prime}, 00^{\prime \prime}$ Lintang Utara sampai dengan $00^{\circ} 23^{\prime} 00^{\prime \prime}$ Lintang Selatan dan $115^{\circ} 05^{\prime}$, 00" Bujur Timur sampai dengan $115^{\circ} 40^{\prime}$ 00" Bujur Timur. Kota inti adalah Kota Pontianak, sedangkan kota-kota satelit meliputi Kota 

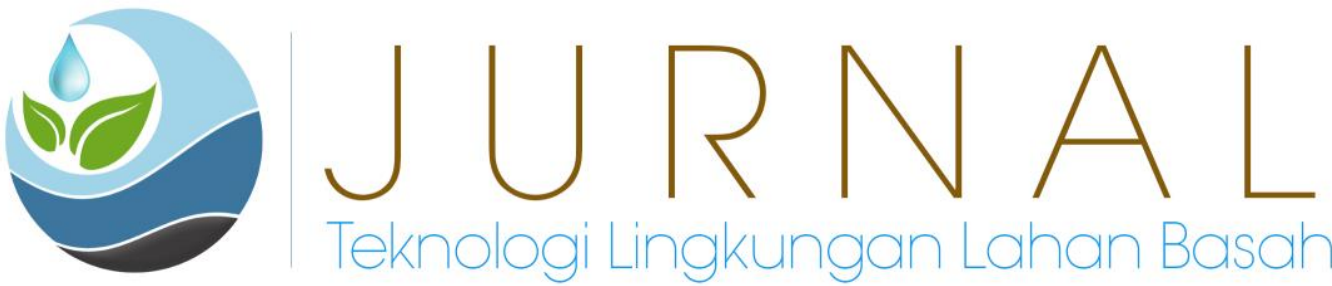

Jungkat, Kuala Mandor, Sungai Ambawang, Sungai Raya, Sungai Kakap dan Rasau.Kawasan Regional Pontianak mempunyai luas sekitar \pm 323 ribu $\mathrm{Ha}$ lebih, terdiri atas 3 wilayah kabupaten/kota dan 12 kecamatan.

Penelitian ini akan membahas mengenai rencana pengembangan infrastruktur air minum sumber daya air (SDA) dilihat dari debit rencana kering di hulu dan kejadian salinitas di hilir serta pengembangan alternatif2sumber air baku yang sesuai dengan konsep pengembangan SPAM untuk memenuhi kebutuhan air minum wilayah Regional Pontianak. Untuk mendapatkan gambaran mengenai kondisi SPAM Regional Pontianak maka dilakukan proses survey di lapangan serta pengumpulan data primer dan sekunder.

Penelitian ini menggunakan pendekatan kuantitatif untuk memperoleh rumusan rencana induk SPAM yang sesuai dengan kaidah-kaidah SPAM berkelanjutan, dengan bantuan software yang ada di Microsoft Excel by Windows 7, Google Earth, Auto-cad 2007.

Untuk menentukan rezim hidrologi di DAS Landak-Kapuas, tahapan yang harus dilaksanakan antara lain: Pengisian atau melengkapi data kosong; analisa curah hujan wilayah; analisa data debit rencana DAS Landak dengan metode historik dan teoritik; analisa debit rencana DAS Ambawang dengan metode F.J. Mock; analisa probabilitas debit tahunan, bulanan dan harian DAS Landak dengan metode diskrit markov; hubungan antara kejadian salinitas dan pasang surut di hilir terhadap debit rencana kering di hulu.
Pada dasarnya sering dijumpai data yang tidak lengkap karena berbagai hal, antara lain kerusakan alat, kelalaian petugas, penggantian alat, bencana dan lain sebagainya. Untuk melengkapi keterbatasan data dari beberapa pos yang ada, maka akan dibantu oleh pos-pos hujan yang berada di sekitar DAS Ambawang dan DAS Landak. Adapun teknik pengisian data yang hilang adalah dengan metode korelasi spasial kuarterner. Namun apabila korelasi bernilai negatif atau data yang tersedia hanya terdapat pada 2 (dua) pos hujan, maka digunakan regresi linier terner atau biner. Korelasi terbesar antara stasiun dipilih sebagai stasiun pengisi dan dibuatkan persamaan regresi sebagai persamaan pengisian data hujan (Arwin,2012). Regresi linier direkomendasikan untuk mengisi data dengan jumlah data kosong yang panjang, dibandingkan dengan cara interpolasi serial yang lebih sederhana (Abatzoglou, 2009).

Setelah itu dilakukan perhitungan hujan wilayah bulanan dan tahunan pada setiap pos hujan yang akan dianalisis. Estimasi curah hujan di suatu wilayah dengan data yang ada melalui pengolahan hidrologi sering dibuat dengan menggunakan metode interpolasi spatial atau metode analisis frekuensi daerah (Benabdesselam, 2013). Pada Das Ambawang dan Das Landak terdapat beberapa alat penakar atau pencatat curah hujan, maka untuk mendapatkan harga curah hujan yang mewakili seluruh areal adalah dengan menggunakan metode Aritmatika.

$$
\bar{R}=\frac{1}{n} \sum_{i=1}^{n} R_{i}(\text { Persamaan 1) }
$$

Dimana:

$\bar{R}=\underset{\text { curah hujan rata-rata wilayah atau }}{\text { daerah }}$ 

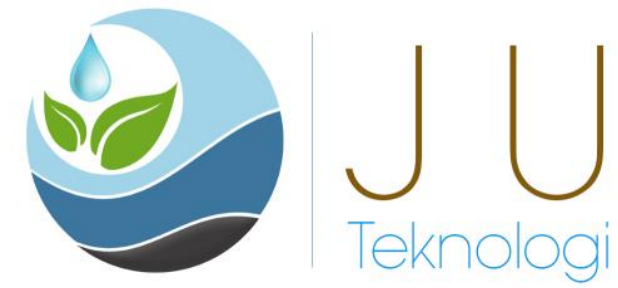

R

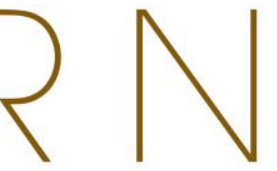

作
$R_{i}=$ curah hujan di stasiun pengamatan ke-i

$\mathrm{n}=$ jumlah stasiun pengamatan

Kebutuhan debit rencana yang diperlukan dalam penyediaan air baku, untuk saat tertentu harus dapat dipenuhi secara keseluruhan oleh debit sungai yang ditinjau, dalam hal ini Sungai Ambawang dan Sungai Landak (Biyung). Analisa keandalan air baku DAS Landak dilakukan dengan metode statistik historik dan teoritik guna memenuhi kebutuhan suplesi di downstream. Metode teoritik dengan cara seleksi dan pengurutan data debit air $1,2,7,15$ dan 30 harian; pemilihan distribusi teoritis (normal, log normal, log person dan gumbel) yang cocok dengan uji Goodness of fit; hitung debit air minimum periode ulang $2,5,10,20$ tahun dengan distribusi teoritis terpilih; kurva peluang debit air minimum ekstrim kering dan didapat keandalan air baku (Arwin, 2006).

Untuk melihat keandalan debit air baku, cara historik juga dapat digunakan. Cara ini menggunakan probabilitas Weibull untuk menghitung probabilitas keandalan sebuah data. Rumus probabilitas weibull menunjukkan nilai probabilitas (setelah data diurutkan dari besar ke kecil) kejadian lebih besar dari nilai tersebut.

$$
\begin{aligned}
& \mathrm{P}(\mathrm{X} \leq \mathrm{x})=\mathrm{m} /(\mathrm{N}+1) \ldots \ldots . .(\text { Persamaan } 2) \\
& \begin{array}{ll}
\text { Dimana } \\
\mathrm{m} \quad & \text { nomor urut kejadian } \\
\mathrm{N}= & \text { jumlah data observasi } \\
\mathrm{P}(\mathrm{X} \leq \mathrm{x})= & \text { peluang terjadinya kejadian } \\
& \text { yang nilainya lebih kecil } \\
& \text { atau sama dengan } \mathrm{x}
\end{array}
\end{aligned}
$$

Analisa keandalan air baku DAS Ambawang dilakukan dengan metode empiris Mock. Dr. F.J. Mock (1973) memperkenalkan model simulasi sederhana keseimbangan air bulanan untuk aliran sungai dari data curah hujan, evapotranspirasi dan karakteristik hidrologi daerah pengaliran (Soeryamasuka, 2001).

Pengembangan intake air baku Sungai Ambawang interbasin Sungai Landak (Biyung) merupakan suatu upaya agar pemenuhan kebutuhan air baku untuk air minum dapat dioptimalkan dan diandalkan. Dimana air baku yang akan digunakan kedepannya tidak terinterusi air asin pada saat musim kemarau dan memiliki kualitas yang sesuai standar melalui pemilihan lokasi intake yang tepat. Kemudian dilakukan pengembangan sistem transmisi air baku sungai Ambawang dan pengembangan IPA terpusat Ambawang yang terintegrasi dengan sistem yang lama dengan pengolahan lengkap untuk memperbaiki kualitas air minum dan mencegah terjadinya ekstrimitas debit.

\section{HASIL DAN PEMBAHASAN}

Sungai Ambawang merupakan anak sungai dari Sungai Landak dengan kedalaman \pm $12 \mathrm{~m}$ dan lebar $\pm 250 \mathrm{~m}$. Sungai Ambawang terletak di kawasan pesisir dengan pola hujan equatorial sehingga hujan terjadi sepanjang tahun (Sarwendah, 2012).

\section{Analisis Pengisian Data Hujan}

Pengisian data hujan perlu dilakukan untuk melengkapi data hujan yang belum terisi. Ketersediaan data curah hujan diperoleh dari 5 pos pengamatan, yakni: Pos Serimbu, Pos Manggu, Pos Untang, Pos Ambawang dan Pos Pontianak. Untuk mengetahui pengaruh antar pos hujan, perlu dilakukan perhitungan korelasi terhadap masing-masing pos hujan. Hasil perhitungan korelasi antar pos hujan 

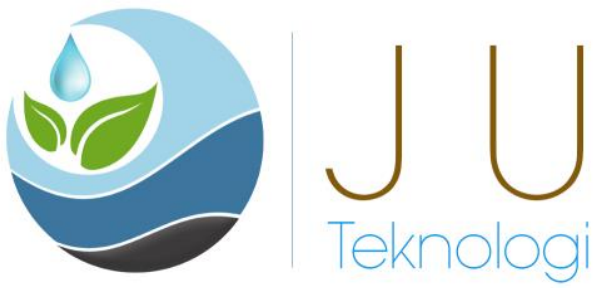

(bivariate) menunjukkan hubungan yang berbeda pada tiap kombinasi pos. Pada waktu tertentu pos hujan memiliki korelasi yang baik, sementara di lain waktu (bulan) dapat berubah. Nilai dari koefisien korelasi (R) terlihat begitu signifikan pada bulan Januari yaitu dengan nilai rata-rata korelasi
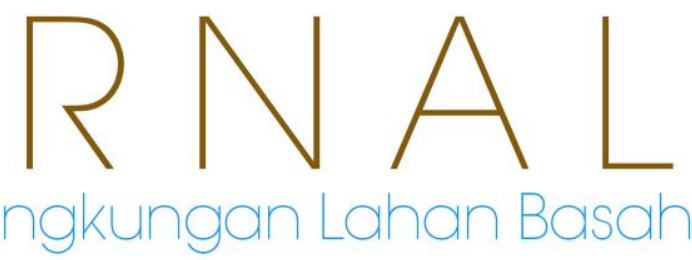

yang cukup besar $(\geq 0,5)$ namun juga terlihat perbedaan pada bulan-bulan selanjutnya, hal ini dikarenakan variabel hidrologi yaitu hujan dan debit yang bersifat acak dan stokastik berdasarkan waktu dan ruang.

Tabel 1. Ketersediaan data hujan (a) dan debit (b)

\begin{tabular}{|c|c|c|c|c|c|c|c|c|c|c|c|c|c|c|c|c|c|c|c|c|c|c|c|c|c|}
\hline Stasfan & $\mathrm{Po}$ & & $\begin{array}{l}19 \\
\text { so }\end{array}$ & $\begin{array}{l}15 \\
51\end{array}$ & $\begin{array}{l}15 \\
92\end{array}$ & $\begin{array}{l}19 \\
93\end{array}$ & $\begin{array}{l}15 \\
54\end{array}$ & $\begin{array}{l}15 \\
95\end{array}$ & $\begin{array}{l}19 \\
465\end{array}$ & $\begin{array}{l}15 \\
57\end{array}$ & \begin{tabular}{|l|}
15 \\
98
\end{tabular} & $\begin{array}{l}19 \\
99 \\
\end{array}$ & \begin{tabular}{|l|}
$x$ \\
解
\end{tabular} & $\begin{array}{l}20 \\
01\end{array}$ & $\begin{array}{l}20 \\
02\end{array}$ & 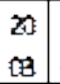 & $\begin{array}{l}20 \\
04\end{array}$ & $\begin{array}{l}20 \\
05\end{array}$ & $x$ & 20 & \begin{tabular}{l|l}
20 & 2 \\
0 & 0
\end{tabular} & \begin{tabular}{l|l}
20 & 21 \\
79 & 1
\end{tabular} & \begin{tabular}{l|l}
20 & 20 \\
10 & 11
\end{tabular} & $\begin{array}{l}20 \\
11\end{array}$ & $\begin{array}{l}20 \\
12\end{array}$ \\
\hline Serimos & 9 & 1 & $\infty$ & & & $x$ & & & $x$ & & & & & & $x$ & & $x$ & & & & & & & & \\
\hline Lnatarke & & 2 & $x$ & & & & & 4 & & & & & 4 & & & & & & & & & & & & \\
\hline ketsegl & & 3 & & & & & & $\Leftrightarrow$ & & & & & & $x$ & & & & $X$ & $x$ & & $x$ & & & X & $x$ \\
\hline A & & 4 & & & & & & & & & & 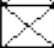 & & & & & & & & & & & & & \\
\hline Pontariek & & 5 & & & & & & & & & & & & & & & & & & & & & & & \\
\hline Stasinan & $\begin{array}{l}\text { Pos } \\
\text { Debit }\end{array}$ & $\begin{array}{l}19 \\
90\end{array}$ & $\begin{array}{l}19 \\
91\end{array}$ & $\begin{array}{l}19 \\
92\end{array}$ & $\begin{array}{l}19 \\
93\end{array}$ & \begin{tabular}{l|}
19 \\
94
\end{tabular} & \begin{tabular}{|l|}
19 \\
95 \\
\end{tabular} & \begin{tabular}{|l|}
19 \\
96
\end{tabular} & $\begin{array}{l}19 \\
97\end{array}$ & $\begin{array}{l}19 \\
98\end{array}$ & \begin{tabular}{l|}
19 \\
99
\end{tabular} & $\begin{array}{l}20 \\
00\end{array}$ & $\begin{array}{l}20 \\
01\end{array}$ & $\begin{array}{l}20 \\
02\end{array}$ & $\begin{array}{l}20 \\
03\end{array}$ & $\begin{array}{l}20 \\
04\end{array}$ & $\begin{array}{l}20 \\
05\end{array}$ & $\begin{array}{l}20 \\
06\end{array}$ & \begin{tabular}{l|}
20 \\
07
\end{tabular} & $\begin{array}{l}20 \\
08\end{array}$ & $\begin{array}{l}20 \\
09\end{array}$ & $\begin{array}{l}20 \\
10\end{array}$ & $\begin{array}{l}0 \\
0\end{array}$ & $\begin{array}{l}20 \\
11\end{array}$ & $\begin{array}{l}20 \\
12\end{array}$ \\
\hline Manggu & Q1 & & & & & & & & & & & & & & & & & & & & & & & & \\
\hline
\end{tabular}

\section{Curah Hujan Wilayah}

Daerah pesisir Kapuas memiliki pola hujan tipe equatorial, ditandai dengan terjadi dua kali puncak hujan yaitu pada bulan April dan bulan Oktober (Tjasyono, 2004). Ratarata hujan wilayah di DAS Landak adalah $284 \mathrm{~mm} / \mathrm{bulan}$ dan di DAS Ambawang 270 $\mathrm{mm} / \mathrm{bulan}$. Wilayah studi memiliki pola hujan tipe equatorial.

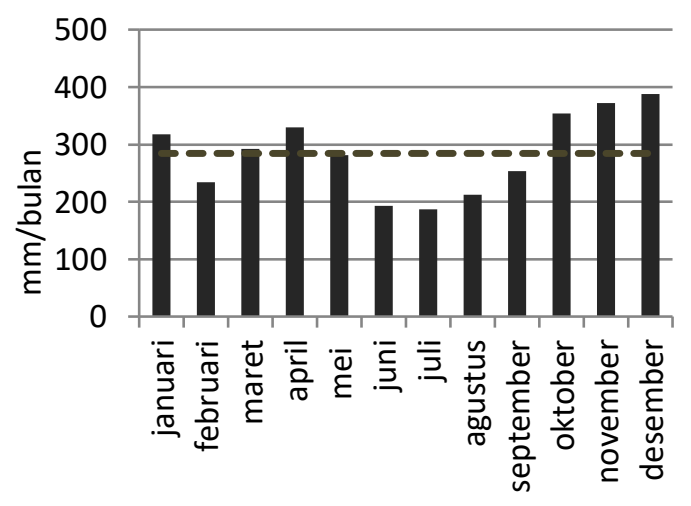

(a) das landak

\section{Debit Andalan}

Besarnya debit andalan ini ditentukan dengan metode rangking (statistik historik)

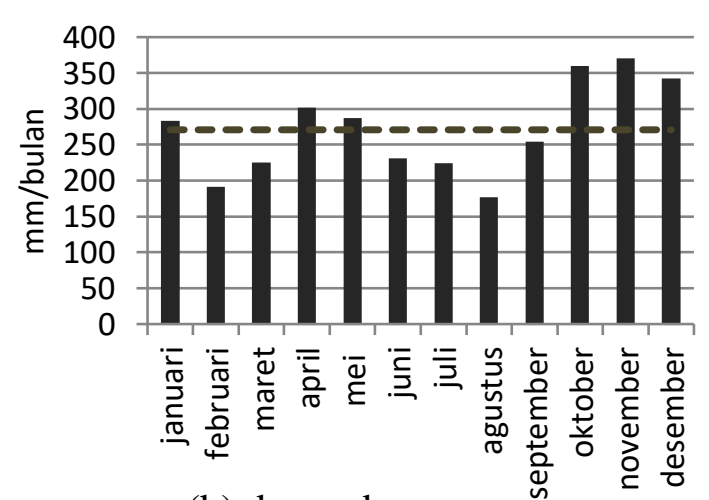

(b) das ambawang

Gambar 1. Grafik curah hujan wilayah rata-rata bulanan atau rasional atau dengan pendekatan metode statistik hidrologi (distribusi 

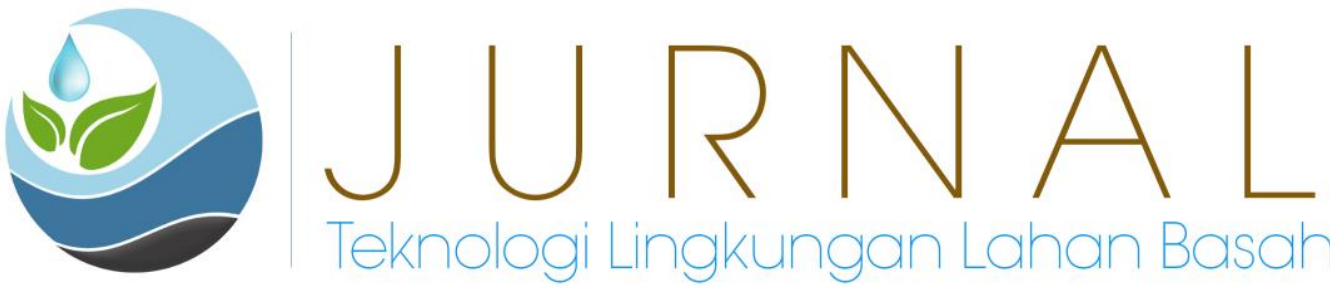

teoritik). Data debit andalan di sungai Ambawang digunakan metode FJ. Mock

yang mengandalkan faktor curah hujan, klimatologi dan faktor lainnya.

Tabel 2. Resume debit andalan pos ambawang (2001-2010)

\begin{tabular}{cc} 
PU & Q kering Lokal Ambawang \\
\hline $\mathbf{5}$ & 21,65 \\
$\mathbf{1 0}$ & 15,30 \\
$\mathbf{2 0}$ & 12,05 \\
$\mathbf{5 0}$ & 10,09 \\
\hline
\end{tabular}

Kebutuhan air baku Regional Pontianak sampai dengan tahun 2030 sebesar 4,6 $\mathrm{m}^{3} /$ det sedangkan debit lokal $\mathrm{R}_{20}$ yang tersedia di Sungai Ambawang sebesar
12,05 $\mathrm{m}^{3} /$ det, sehingga sampai dengan tahun 2030 kebutuhan air baku Regional Pontianak dapat

\section{Kejadian Salinitas dan Pengaruh Pasang Surut}

Sungai Ambawang interbasin Sungai Landak terpilih sebagai alternatif sumber air baku yang baru, namun ternyata sungai ambawang secara periodik terpengaruh pasang surut yang memiliki potensi interusi air laut.

Sumber air baku di wilayah Regional Pontianak sangat terpengaruh dengan pasang surut dan salinitas dengan nilai yang jauh di atas baku mutu terutama pada musim kering dan normal sehingga dianalisa debit rencana kering (moving average) di Pos Manggu. Debit rencana kering sepanjang 18 tahun yang dibagi dalam 2 periode yaitu I (1995-2003) dan II (2004-2012), tidak terdapat degradasi rezim hidrologi di DAS Hulu sehingga peningkatan salinitas tidak disebabkan degradasi debit rencana kering pada DAS Hulu. Hal ini juga dibuktikan pada Gambar 2 yang memperlihatkan peningkatan debit tahunan sepanjang 18 tahun dengan garis linier yang semakin ke atas.

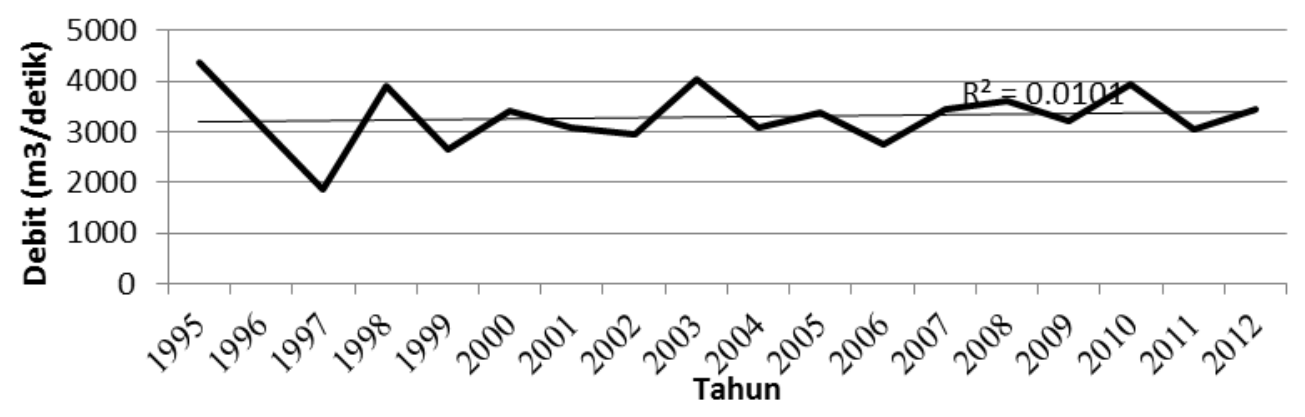

Gambar 2. Debit Tahunan Pos Manggu 1995-2012 

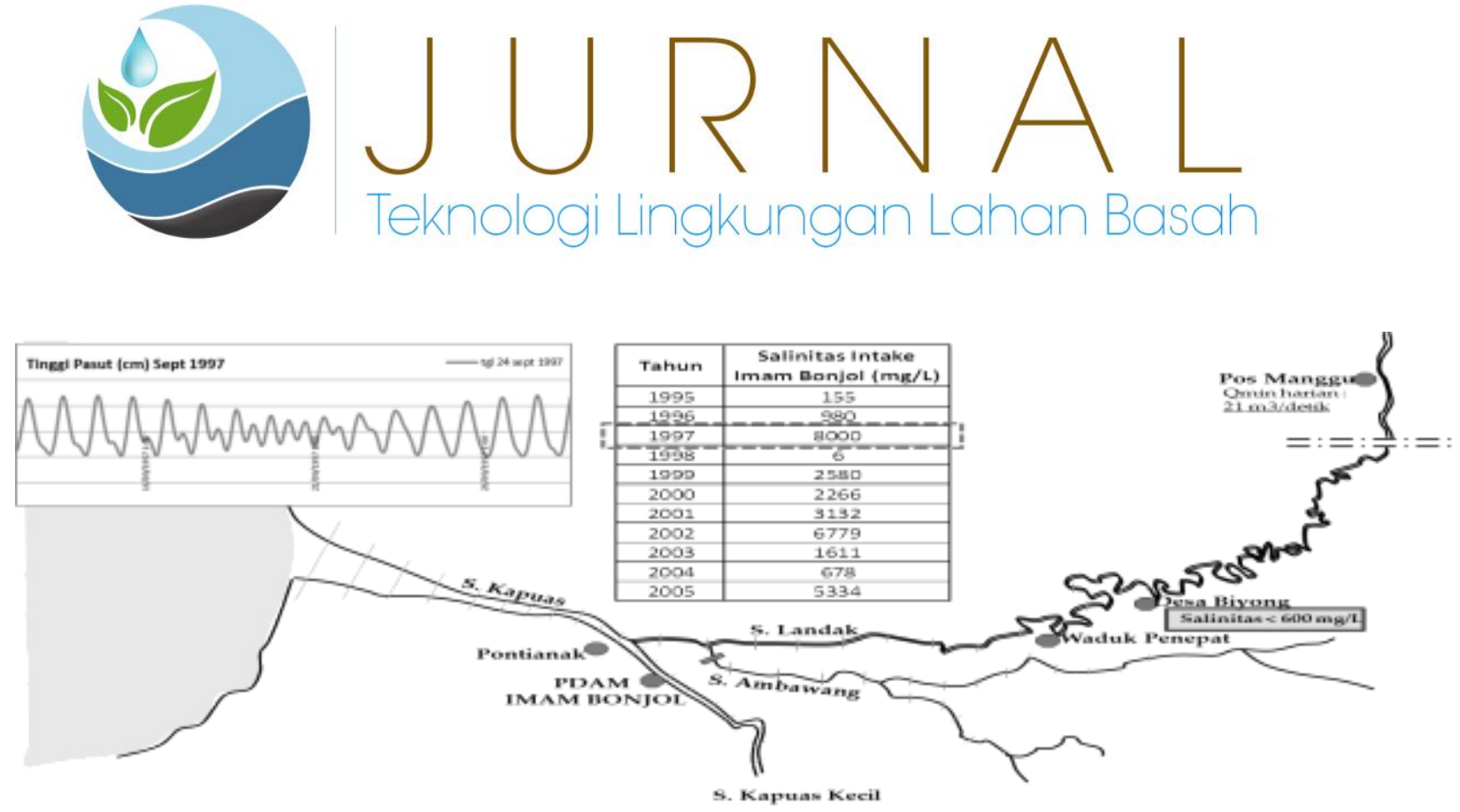

Gambar 3. Boundary condition problem

Standar salinitas untuk air baku air minum yang telah ditetapkan yaitu $400 \mathrm{mg} / \mathrm{l}$, namun untuk wilayah pesisir Kalimantan Barat melalui keputusan Gubernur Kalimantan Barat, standar salinitas air baku menjadi $600 \mathrm{mg} / \mathrm{l}$. Masalah salinitas sangat tergantung pada besaran boundary condition. Gambar 3 menunjukkan bahwa salinitas yang paling tinggi terjadi ketika pasang maksimum pada tahun kering, bulan kering dan debit harian minimum namun salinitas juga dapat terjadi pada tahun normal. Sehingga apabila pasut maksimum namun debit di hulu besar, interusi air laut tidak akan jauh ke hulu. Debit harian minimum tercatat pada tahun 1997 sebesar $21 \mathrm{~m}^{3} /$ detik analog dengan debit rencana 20 tahun kering 1 harian $\left(\mathrm{R}_{20}\right.$ 1 harian) sebesar $23,38 \mathrm{~m}^{3} /$ detik. Pada tahun basah tidak terjadi salinitas karena debit kering dari DAS Hulu cukup besar sehingga pasang air laut tertahan dan nilai salinitas tidak begitu besar.

Tabel 3. Debit historis, kelas debit dan salinitas

\begin{tabular}{|c|c|c|c|c|c|c|c|c|c|c|c|c|c|}
\hline \multirow{2}{*}{ No } & \multirow{2}{*}{ Tahun } & \multicolumn{2}{|c|}{ Debit Tahunan } & \multicolumn{3}{|c|}{ Debit Bulanan } & \multicolumn{3}{|c|}{ Debit Harian } & \multicolumn{2}{|c|}{ Tinggi Pasut (cm) } & \multicolumn{2}{|c|}{ Salinitas } \\
\hline & & $\operatorname{Vol}\left(10^{6} \mathrm{~m}^{3}\right)$ & Kelas & Bulan & Debit & Kelas & Tgl & Debit & Kelas & Tertinggi & Terendah & Imam Bonjol & Penepat \\
\hline 1 & 1995 & 11453,7 & 2 & Juni & 219,4 & 1 & 20-Dec & 103,00 & 2 & 46,50 & $-42,30$ & 155 & - \\
\hline 2 & 1996 & 8199,3 & 1 & May & 149,74 & 0 & 15-Aug & 49,00 & 0 & 64,02 & $-53,35$ & 980 & - \\
\hline 3 & 1997 & 4869,9 & 0 & September & 38,57 & 0 & 23-Sep & 21,00 & 0 & 48,40 & $-45,50$ & 8000 & 2628 \\
\hline 4 & 1998 & 10227,4 & 2 & Juni & 158,53 & 0 & $15-F e b$ & 110,04 & 2 & 46,60 & $-42,00$ & 6 & - \\
\hline 5 & 1999 & 6953,8 & 0 & Februari & 74,42 & 0 & $25-\mathrm{Feb}$ & 21,29 & 0 & 48,05 & $-39,86$ & 2580 & - \\
\hline 6 & 2000 & 8970,5 & 1 & Juli & 125,06 & 0 & 19-Jul & 79,14 & 1 & 68,70 & $-65,40$ & 2266 & - \\
\hline 7 & 2001 & 8113,3 & 1 & Juli & 144,14 & 0 & 15-Jul & 72,91 & 1 & 14,00 & $-13,00$ & 3132 & - \\
\hline 8 & 2002 & 7777,0 & 0 & Juli & 88,91 & 0 & 26-Aug & 68,56 & 1 & 74,00 & $-71,00$ & 6779 & - \\
\hline 9 & 2003 & 10620,9 & 2 & Agustus & 106,96 & 0 & 4-Aug & 31,95 & 0 & 120,00 & 70,00 & 1611 & - \\
\hline 10 & 2004 & 8061,8 & 0 & Agustus & 109,03 & 0 & 1-Sep & 57,41 & 0 & 150,00 & 30,00 & 678 & - \\
\hline 11 & 2005 & 8861,9 & 1 & Agustus & 138,21 & 1 & $11-\mathrm{Feb}$ & 66,45 & 0 & 180,00 & 30,00 & 5334 & - \\
\hline 12 & 2006 & 7265,0 & 0 & Agustus & 121,66 & 0 & 8-Oct & 75,01 & 1 & 120,00 & 70,00 & - & - \\
\hline 13 & 2007 & 9027,8 & 1 & Juli & 170,59 & 1 & 7-Oct & 99,99 & 1 & 180,00 & 40,00 & - & - \\
\hline 14 & 2008 & 9515,1 & 2 & May & 182,17 & 0 & 22-May & 91,60 & 1 & 200,00 & 20,00 & - & - \\
\hline 15 & 2009 & 8420,5 & 1 & September & 125,16 & 0 & 2 -Oct & 90,07 & 1 & 150,00 & 60,00 & - & - \\
\hline 16 & 2010 & 10365,1 & 2 & Juni & 243,21 & 2 & 27-Jun & 139,37 & 2 & 200,00 & 20,00 & - & - \\
\hline 17 & 2011 & 8024,9 & 0 & Agustus & 123,17 & 0 & 13-Aug & 97,80 & 2 & 190,00 & 30,00 & - & - \\
\hline 18 & 2012 & 9037,3 & 2 & Agustus & 147,03 & 1 & 25-Jun & 68,97 & 1 & 64,73 & $-57,75$ & - & - \\
\hline
\end{tabular}



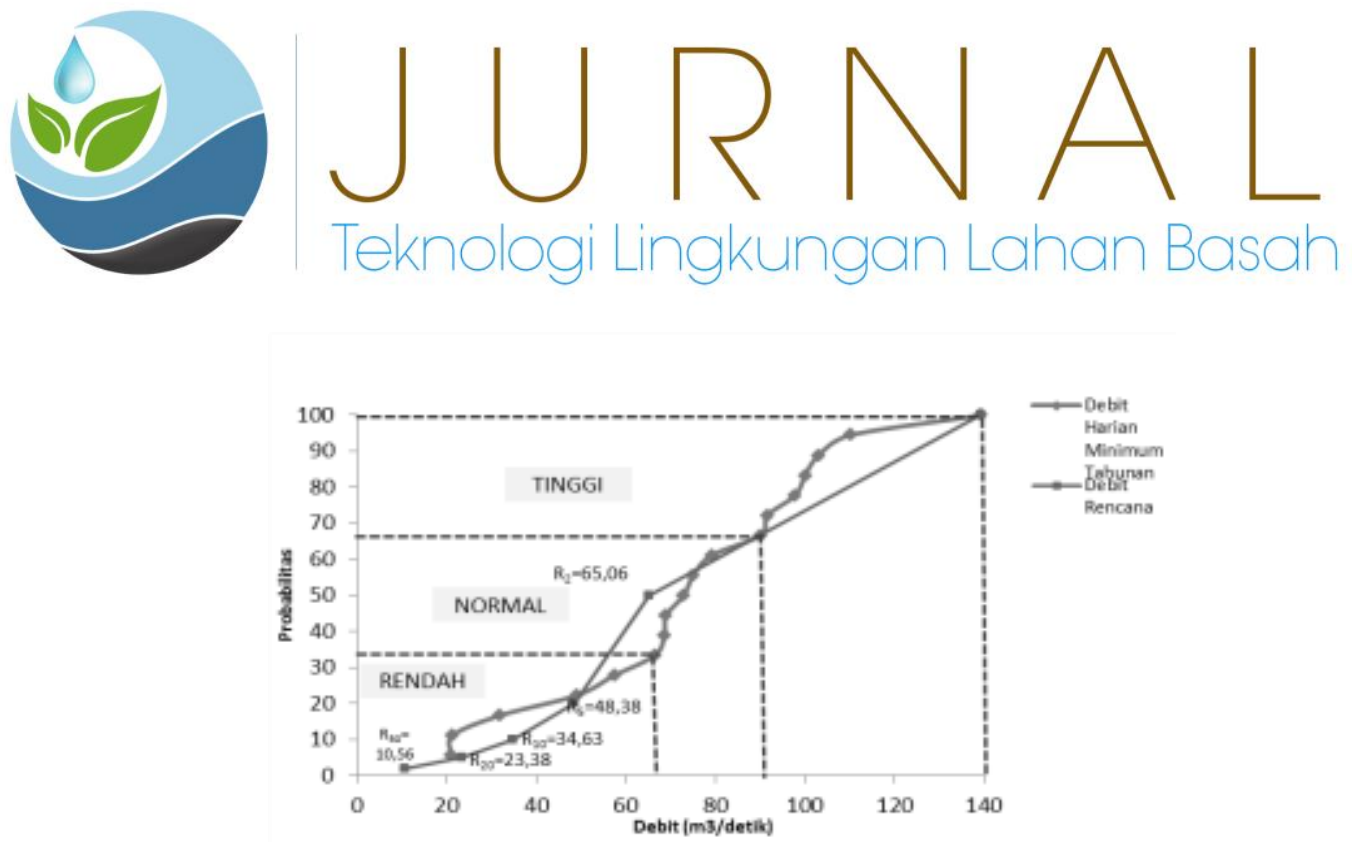

Gambar 4. Verifikasi debit harian minimum vs debit rencana di pos manggu 1995-2012

\section{Perencanaan Long Storage Ambawang dan Saluran Supplesi}

Long Storage Ambawang sepanjang \pm 27 $\mathrm{km}$ berfungsi untuk mempertahankan debit yang dibutuhkan untuk air minum sampai dengan tahun 2030 dan untuk memutus pengaruh salinitas pada saat pasang surut dengan bendungan. Sehingga perlu direncanakan bendungan yang dapat memutus salinitas pada Sungai Ambawang dengan tinggi bendungan 11,61 m (tinggi muka air pasang tertinggi)+ tinggi jagaan $0,5 \mathrm{~m}=12,11 \mathrm{~m}$; lebar bendungan menyesuaikan lebar sungai yaitu $200 \mathrm{~m}$.

Tabel 4. Skenario debit ambawang dan suplesi

\begin{tabular}{|c|c|c|}
\hline \multirow{2}{*}{$\begin{array}{c}\text { PU } \\
\text { (tahun) }\end{array}$} & Lokal Ambawang & Suplesi \\
\cline { 2 - 3 } & $\begin{array}{c}\text { Qkering } \\
\text { (m3/detik) }\end{array}$ & $\begin{array}{c}\text { Q konstan } \\
\text { (m3/detik) }\end{array}$ \\
\hline R5 & 21,65 & 12,05 \\
\hline R10 & 15,30 & 12,05 \\
\hline R20 & 12,05 & 12,05 \\
\hline
\end{tabular}

Dengan kontrol $\mathrm{R}_{20}$ kering biyung yaitu $57,82 \mathrm{~m}^{3} /$ detik. Maka direncanakan debit yang akan diambil untuk masuk ke long storage yaitu lebih besar atau sama dengan $\mathrm{R}_{20}$ kering lokal Ambawang yaitu 12,05 $\mathrm{m}^{3} /$ detik (1:1) agar terjadi reklamasi air. Untuk mengalirkan debit tersebut diperlukan saluran yang berbentuk trapezium dengan dimensi: lebar bawah 1,5 m; lebar atas 7,9 m; kedalaman 3,2 m; dan memiliki kecepatan $0,79 \mathrm{~m} /$ det. Pintu air yang digunakan untuk saluran suplesi yaitu pintu sorong (sliding gate).

\section{Pengembangan Infrastruktur Air Minum Regional Pontianak}

Dalam hal pengembangan SPAM Regional Pontianak akan dilakukan secara terintegrasi dengan sistem yang lama. Pengembangan Intake Ambawang dilakukan untuk meningkatkan pelayanan fasilitas air minum dalam hal suplai air baku. Pada tahun 2015, IPA Imam Bonjol Kota Pontianak akan dilakukan penambahan kapasitas 300 liter/detik, sehingga kapasitasnya menjadi 1.160 liter/detik, dimana semula hanya 860 liter/detik. IPA Sungai Jawi Luar (SJL) berkapasitas 50 liter/detik dan IPA Selat Panjang berkapasitas 300 liter/detik. Saat ini juga telah dilakukan pembangunan IPA Timur dengan kapasitas 300 liter/detik. Selain itu juga, IPA Kab. Pontianak berkapasitas 155 liter/detik dan IPA Kab. Kubu Raya berkapasitas 160 liter/detik. 

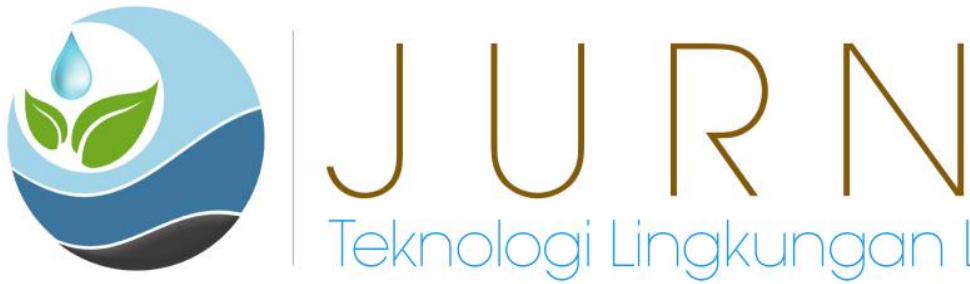

J

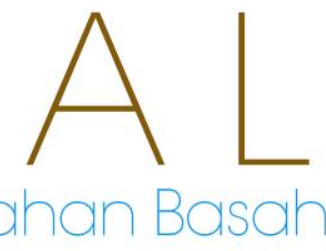

Sehingga Intake Ambawang kapasitasnya menjadi 2.125 liter/detik, pipa transmisi yang akan dipakai bertipe HDPE, supaya tidak terjadi kebocoran pipa akibat korosif akibat lingkungan yang kurang mendukung. Pipa transmisi akan melewati tanah gambut yang sangat tebal dengan keasaman tanah yang tinggi, sehingga dapat menyebabkan korosi pada pipa jenis DCIP. Pada pemilihan diameter pipa dilakukan dengan melakukan perhitungan variasi diameter (100-1500 mm), sehingga didapat headloss dan kecepatan yang diijinkan pada masing-masing jalur. Program Jangka Menengah (2016-2020) akan dilakukan pergantian sumber air baku dari Sungai Ambawang; pemasangan dan pengoperasian pipa transmisi pengaliran air baku ke seluruh IPA (Timur, Imam Bonjol, SJL, Arang Limbung, Kuala dua, Selat Panjang dan Siantan); pemasangan pipa transmisi pengaliran ke IPA Ambawang; pembangunan IPA Ambawang secara bertahap (Q 1500 liter/detik dan Q 1000 liter/detik). Sedangkan Program Jangka Panjang (2020-2030) yaitu Pengoperasian IPA Ambawang secara bertahap (Tahap 1: Q 1500 liter/detik, Tahap 2: Q 1000 liter/detik) dan Manajemen waduk Ambawang.

\section{PENUTUP}

RIP-SPAM Regional Pontianak merupakan strategi perencanaan sumber air baku dan pengembangan SPAM Regional Pontianak yang adaptif terhadap kejadian pasang tertinggi di muara pada tahun normal dan kering sehingga berdampak pasang surut dan interusi air laut semakin meningkat pada tahun kering menuju daratan yang dipengaruhi tipe hujan equatorial. Dari hasil analisa fuktuasi tinggi muka air, Sungai Ambawang secara periodik terpengaruh pasang surut dan salinitas > $400 \mathrm{mg} / \mathrm{L}$ pada musim kering dan normal, sedangkan Sungai Landak (Biyung) sampai saat ini tidak terpengaruh salinitas, memiliki debit yang acak dan dipengaruhi oleh curah hujan dari DAS Landak. Kejadian salinitas tertinggi terjadi pada saat pasang maksimum pada tahun kering, bulan kering dan debit harian minimum sebesar $21 \mathrm{~m}^{3} /$ detik analog dengan debit rencana 20 tahun kering 1 harian $\left(\mathrm{R}_{20} 1\right.$ harian $)$ sebesar 23,38 $\mathrm{m}^{3} /$ detik.

Kebutuhan air baku Regional Pontianak sampai dengan tahun 2030 sebesar 4,6 $\mathrm{m}^{3} /$ det sedangkan debit lokal $R_{20}$ yang tersedia di Sungai Ambawang sebesar $12,05 \mathrm{~m}^{3} /$ det, dan $\mathrm{R}_{20} 1$ harian di Pos Manggu sebesar 23,38 $\mathrm{m}^{3} /$ detik sehingga sampai dengan tahun 2030 kebutuhan air baku Regional Pontianak dapat terpenuhi.

\section{DAFTAR PUSTAKA}

Abatzoglou, J.T. 2009. Classification of Regional Climate Variability in The State of California, Journal of Applied Meteorology and Climatology. Desert Research Institute, Reno, Nevada.

Arwin. (2012). Sumber Air \& Pengembangan SPAM Perkotaan Berkelanjutan Riset Zona Hujan tipe Munsoon Konsinyasi Monev Ketersediaan Air Baku dan Kebutuhan Air Minum dalam rangka Pengembangan SPAM, BPPSPAM -KPU

Arwin dan Mukmin, Y. (2006). Kajian Keandalan Air Sungai Cisadane Memenuhi Laju Permintaan Air Baku PDAM Kota Bogor, Jurnal Perencanaan Wilayah dan Kota, 

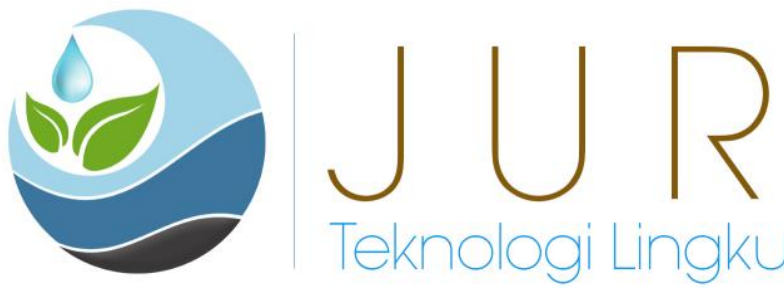

.
Vol.17/No.2, hlm. 53-74.Institut Teknologi Bandung, Indonesia

Arwin dan Ridwan, L.M. (2009). Sumber Air Baku \& Peningkatan Pelayanan Air Minum Perkotaan Kawasan Pesisir Pantai: Kasus PAM Kota Pontianak. Semiloka Nasional Peningkatan Pelayanan Air MinumMenuju MDGs 2015.

Basu, Sudevi and Lokesh, K S. 2013. Spatial and temporal variations of river water quality: A case study of River Kabini at Nanjangud in Karnataka, International Journal of Water Resources dan Environmental Engineering Vol 5 (10); Oktober 2013, Department of Biotechnology, Sir MVisvesvaraya Institute of Technology, Bangalore, Karnataka, and Department of Environmental Engineering, Sri Jayachamarajendra College of Engineering, Mysore, Karnataka.

Benabdesselam, Tamara and Amarchi, Hocine. 2013. Regional Approach for the Estimation of Extreme Daily Precipitation on North-East Area of Algeria, International Journal of Water Resources and Environmental Engineering Vol 5 (10). Department of Hydraulic, Badji Mokhtar-Annaba University, Algeria.

Fitria, Laili. (2012). Kajian Strategis Pengembangan SPAM Kota Pontianak (RIP-SPAM) Dalam Rangka Pencapaian Target MDGs 2015. Departemen Teknik Lingkungan FTSL ITB, Tesis.

Khan, E., Ireson, A., Kovats, S., Mojumder, S.K., Khusru, A., Rahman, A., and Vineis, P. 2011. Drinking Water Salinity and Maternal Health in Coastal
Bangladesh: Implications of Climate Change, Journal of Environ Health Respect Vol 119(9). National Institut of Health.

Ramos, H. M., Mello, M., dan De, P. K. 2010. Clean Power in Water Supply Systems as A Sustainable Solution: from Planning to Practical Implementation, Journal of Water Science \& Technology: Water Supply, Vol. 10 No. 1. IWA Publishing. United States.

Sarwendah, Ratih. (2011). Kajian Long Storage Ambawang sebagai Sumber Air Baku Pengembangan SPAM Regional Pontianak Kawasan Pesisir Kapuas. Departemen Teknik Lingkungan FTSL ITB, Tugas Akhir.

Soeryamasuka, S.B. (2001). Tinjauan Ph Dan Salinitas Sungai Ambawang Untuk Intake Pengambilan Air Bersih Optimum Kota Pontianak. Departemen Teknik Sumber Daya Air ITB, Tugas Akhir.

Tamin. (2007). Kebijakan Strategis Pengembangan Air Minum Di Kawasan Andalan Kasus Jabodetabek. Direktorat Pengembangan Air Minum. Dirjen Cipta Karya-Departemen PU.

Tjasyono, Bayong. (2004). Klimatologi. Institut Teknologi Bandung, Bandung. 